\title{
Hepatic complications of peptide receptor radionuclide therapy with Lutetium-177 and Yttrium-90 in patients with neuroendocrine neoplasm
}

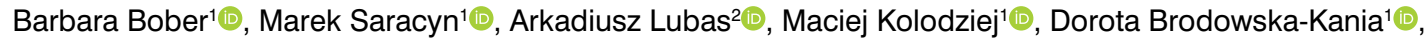 \\ Waldemar Kapusta' ${ }^{\circledR}$, Grzegorz Kaminski1 ${ }^{10}$ \\ ${ }^{1}$ Department of Endocrinology and Isotope Therapy, Military Institute of Medicine, Warsaw, Poland \\ ${ }^{2}$ Department of Internal Diseases, Nephrology and Dialysis, Military Institute of Medicine, Warsaw, Poland
}

[Received 1901 2022; Accepted 2401 2022]

\begin{abstract}
Neuroendocrine neoplasms (NENs) are a heterogeneous group of tumors originating from neuroendocrine cells spread throughout the body, forming the so-called diffuse endocrine system. The gold standard in treating unresectable or disseminated, progressive, and well-differentiated NENs is therapy with radiolabeled somatostatin analogs (peptide receptor radionuclide therapy PRRT). PRRT is a method based on peptides combined with beta-emitting radionuclides. The study aimed to assess the early and long-term liver complications after administration of Lutetium-177 or Lutetium-177 combined with Yttrium-90. We enrolled 27 patients treated with [ $\left.{ }^{177} \mathrm{Lu}\right] \mathrm{Lu}$-DOTATATE with an activity of $7.4 \mathrm{GBq}(200 \mathrm{mCi})$ and 9 patients received the tandem treatment [90Y]Y-DOTATATE + [177 Lu]Lu-DOTATATE with an activity of $3.7 \mathrm{GBq}(50 \mathrm{mCi}+50 \mathrm{mCi})$. In the assessment of early as well as long-term complications, no significant effect of the applied treatment on the parameters of liver injury was found. Regarding liver function PRRT was a safe treatment for patients with highly or moderately differentiated, unresectable, or diffuse NENs.
\end{abstract}

KEY words: neuroendocrine neoplasms; treatment of neuroendocrine neoplasms; radioisotope treatment; PRRT; complications of radioisotope treatment

Nucl Med Rev 2022; 25, 1: 54-61

\section{Introduction}

Neuroendocrine neoplasms (NENs), formerly called neuroendocrine tumors (NETs), constitute a heterogeneous group of neoplasms. They come from neuroendocrine cells spread throughout the body, forming the so-called diffuse endocrine system (DES). They are considered rare neoplasms, but modern imaging techniques have rapidly increased their detection over the last decades [1-4]. Since 1973, in the United States alone, the number of diagnosed cases of NENs has increased over five times. Currently, the overall incidence rate of NENs is 35 cases per

Correspondence to: Barbara Bober, Department of Endocrinology and Isotope Therapy, Military Institute of Medicine, Szaserów 128 04-141 Warsaw, Poland; phone: +48 261816110 , e-mail: barbara.bober@tlen.pl
100,000 persons. The most common location of NENs in the human body is the small intestine, in particular the ileum [5], and $70 \%$ of NENs are gastroenteropancreatic (GEP NEN), i.e. about $2 \%$ of the general population of gastrointestinal neoplasms [6, 7].

Although the endoscopic or surgical removal of the tumor is the only method of treating the patient ultimately [8-10], the most significant progress in the treatment of highly differentiated NENs of the gastrointestinal tract was achieved by introducing somatostatin analogs (SSA) in 1988 [11]. The analogs bind to the somatostatin receptor causing the inhibition of the cell cycle and inducing a proapoptotic effect. They also have an immunomodulating effect, inhibit angiogenesis, and inhibit the secretion of hormones [12]. Treatment with radioisotope-labeled somatostatin analogs (peptide receptor radionuclide therapy — PRRT) has been used for over 20 years. This method uses peptides combined with radionuclides emitting beta or alpha radiation $[13,14]$. In Poland, $\left[{ }^{0} Y\right]$ Y-DOTATATE was used for the first time in April 2004, and

This article is available in open access under Creative Common Attribution-Non-Commercial-No Derivatives 4.0 International (CC BY-NC-ND 4.0) license, allowing to download articles and share them with others as long as they credit the authors and the publisher, but without permission to change them in any way or use them commercially. 
in February 2006 tandem treatment $\left[{ }^{90} \mathrm{Y}\right] \mathrm{Y} /\left[{ }^{177} \mathrm{Lu}\right] \mathrm{Lu}$-DOTATATE was initiated [15].

The current regimen of PRRT treatment consists of 4 administrations of a selected isotope with a specific activity at eight- to twelveweek intervals. The most common side effects are kidney injury and myelosuppression, found relatively rarely in patients treated with PRRT [13]. Acute hematological complications (World Health Organization [WHO] grade 3 or 4 ) occur in less than $13 \%$ of patients receiving Yttrium-90 and 3\% of patients receiving Lutetium-177. On the other hand, acute renal complications depend mainly on the radiopharmaceuticals' activity and comorbidities [16-20]. There are limited data on hepatic complications. The Endocrinology and Isotope Therapy Department of the Military Institute of Medicine in Warsaw covers the largest group of patients with NENs undergoing PRRT in Poland and Central and Eastern Europe. Due to the small number of studies and inconclusive results, we decided to assess such complications in this group of patients.

The study aimed to assess the early and long-term hepatic complications after radioisotope treatment using Lutetium-177 or Lutetium-177 in combination with Yttrium-90 in patients with neuroendocrine neoplasm.

\section{Material and methods}

\section{Study population}

The presented paper is a preliminary study evaluating early and long-term complications of radioisotope treatment in patients with NENs. The study group consisted of 36 patients treated with PRRT due to NENs from November 2017 to June 2019 in the Department of Endocrinology and Isotope Therapy of the Military Institute of Medicine in Warsaw. All patients qualified to PRRT at that time gave their written consent to participate in the study.

The local Bioethics Committee approved the study at the Military Institute of Medicine. All procedures carried out in the study followed the Helsinki Declaration of 1964 and its subsequent changes. Patients to be enrolled had to meet the following inclusion criteria: a) a highly differentiated, progressive neuroendocrine neoplasm defined as Ki-67 < 20\% (progression within the last 12 months); b) good expression of somatostatin receptors in a qualifying receptor scintigraphy study (single photon emission computed tomography [SPECT]) or positron emission tomography/computed tomography (PET/CT); c) no more options for surgical treatment possible and d) chronic treatment with long-acting somatostatin analogs. The exclusion criteria were: a) the patient's lack of consent to treatment; b) pregnancy or lactation; c) assessment of the patient's performance status based on the World Health Organization/Eastern Cooperative Oncology Group (WHO/ECOG) status 3 or 4 or the basis of the Karnofsky classification $(<60)$; d) no uptake of the radiotracer in the somatostatin receptors imaging (SRI); e) bone marrow failure: hemoglobin less than $8 \mathrm{~g} / \mathrm{dL}$, platelets less than $80 \times 10^{3} / \mu \mathrm{L}$, leukocytes below $2 \times 10^{3} / \mu \mathrm{L}$, lymphocytes below $0.5 \times 10^{3} / \mu \mathrm{L}$, neutrophils less than $1 \times 10^{3} / \mu \mathrm{L} ; \mathrm{f}$ ) creatinine clearance $<30 \mathrm{~mL} / \mathrm{min}$, blood urea nitrogen over $45 \mathrm{mg} / \mathrm{dL}$ or serum creatinine concentration over $1.8 \mathrm{mg} / \mathrm{dL} ; \mathrm{g}$ ) liver injury (3-fold increase in bilirubin); h) systemic infections; i) glomerulonephritis; j) interstitial nephritis; k) obstructive nephropathy or l) urinary tract infection.

\section{Treatment strategies}

Patients were given an intravenous infusion of [ $\left.{ }^{177} \mathrm{Lu}\right] \mathrm{Lu}-\mathrm{DO}$ TATATE with an activity of $7.4 \mathrm{GBq}(200 \mathrm{mCi})$ or tandem treatment

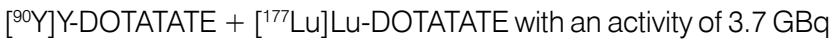
(50 mCi $+50 \mathrm{mCi}$ ) (ItraPol and LutaPol, manufacturer: National Center for Nuclear Research, POLATOM Radioisotope Center, Otwock, Poland). In addition, selected biochemical parameters were assessed before and after the radioisotope administration. For two days, patients also received infusions of $10 \%$ amino acid solution (Nephrotect, Fresenius Kabi) (1000 mL on the first day, $500 \mathrm{~mL}$ on the second day) and Ringer's solution $(2 \times 500 \mathrm{~mL})$. Treatment with long-acting somatostatin analogs (octreotide - Sandostatin LAR; Novartis and lanreotide autogel - Somatuline; Ipsen) was discontinued for at least four weeks prior to PRRT administration. The time since completion of prior chemotherapy was more than three months.

In total, the therapy (4 courses) lasted on average nine months (7-11 months). After the fourth course, patients were scheduled for follow-up visits, which were performed approximately 18 months from the start of the therapy (10 months from the end of radioisotope treatment). The following parameters were checked at each stage of the study: serum albumin, alanine aminotransferase (ALT), aspartate aminotransferase (AST), and bilirubin. Detailed procedures are as follows: day 1 - history taking and physical examination, serum albumin, ALT, AST, bilirubin; day 2 - intravenous administration of $1000 \mathrm{~mL}$ of positively charged amino acids with a simultaneous infusion of $500 \mathrm{~mL}$ Ringer's solution - a continuous infusion of 8 hours, intravenous infusion of radioisotopes $\left[{ }^{177} \mathrm{Lu}\right] \mathrm{Lu}-$ DOTATATE or $\left[{ }^{0} \mathrm{Y}\right]$ Y-DOTATATE $+\left[{ }^{177} \mathrm{Lu}\right]$ Lu-DOTATATE (a radiopharmaceutical solution in $100 \mathrm{~mL} 0.9 \% \mathrm{NaCl}$ ); day 3 - intravenous administration of $500 \mathrm{~mL}$ of positively charged amino acids with a simultaneous infusion of $500 \mathrm{~mL}$ of Ringer's fluid - a continuous infusion of 4 hours; day 4 - serum albumin, ALT, AST, bilirubin, post-therapeutic scintigraphy, and patient's discharge. Follow-up tests (clinical and laboratory) were performed during a one-day hospitalization. The biochemical tests were performed in the Department of Laboratory Diagnostics of the Military Institute of Medicine using an automatic biochemical analyzer (Cobas C 501, Roche Diagnostics).

\section{Statistical methods}

Statistical analyzes were performed with the use of the IBM SPSS Statistics 25. It was used to analyze basic descriptive statistics with the Shapiro-Wilk test, two-factor analysis of variance in a mixed schema, and Mann-Whitney $U$ tests. The classical threshold $\alpha=0.05$ was considered the level of significance. Acute complications were assessed during the $1^{\text {st }}$ and $4^{\text {th }}$ course. Long-term complications were evaluated based on comparing the results obtained before the 1 st course, before the $4^{\text {th }}$ course, and during the follow-up examination. Data were also analyzed depending on the type of the applied therapy, sex, age, BMI, 
comorbidities (chronic kidney disease, diabetes, hypercholesterolemia, hypertension), NEN point of origin, and the history of chemotherapy.

\section{Results}

The study group consisted of 36 patients, including 16 women (44.5\%) and 20 men (55.5\%). Details are presented in Table 1. The mean age was $58.1 \pm 13.1$. Twenty-seven patients received [ $\left.{ }^{177} \mathrm{Lu}\right]$ Lu-DOTATATE with an activity of $7.4 \mathrm{GBq}(200 \mathrm{mCi})$, and nine patients received the tandem treatment $\left[{ }^{90} \mathrm{Y}\right] \mathrm{Y}$-DOTATATE $+\left[{ }^{177} \mathrm{Lu}\right]$ Lu-DOTATATE with an activity of $3.7 \mathrm{GBq}(50 \mathrm{mCi}+50 \mathrm{mCi})$. Thirty patients completed full treatment ( 6 dropouts: 2 - disease progression, 1 - myelosuppression, 1 - the death of unknown cause, 2 - withdrawals). Long-term follow-up was not performed in 11 patients because of the Covid-19 pandemic.

The mean body mass index (BMI) was $24.9 \mathrm{~kg} / \mathrm{m}^{2}$, and $50 \%$ of patients had normal BMI values. The most common comorbidities were arterial hypertension (41.66\%) and diabetes (27.8\%). Their frequency was significantly higher in the studied group than in the general population $(41.66 \%$ vs $31.5 \%$ in the case of hypertension and $27.8 \%$ vs $9.1 \%$ in the case of diabetes). Pancreatic NENs (13/36) and small intestine NENs (11/36) were the most frequent. The percentage of patients with G1 and G2 stages was similar (47.2\% vs $52.8 \%$ ). The median time from disease diagnosis to initiation of radioisotope treatment was 3.4 years (range $0-15$ years).

Most patients had liver metastases $(91,7 \%)$. The three remaining cases had metastases only to lymph nodes and bone, including pulmonary NENs, paraganglioma, and one case with an unknown point of origin. Before PRRT therapy, 6 patients received chemotherapy for: NEN (1 patient - doxorubicin with etoposide, $2^{\text {nd }}$ patient - everolimus, $3^{\text {rd }}$ - capecitabine with temozolomide), breast cancer (1 patient, drug unknown), and colorectal adenocarcinoma (2 patients, unknown drugs). Before PRRT $77,8 \%$ of patients had primary NEN lesions surgically removed. Only in 8 cases, the primary tumor was not removed ( 1 patient did not consent to surgical treatment of a pancreatic tumor, in 6 patients, the lesions were unresectable at the time of diagnosis, one person could not be operated on due to anesthetic contraindications). Additionally, hemihepatectomy was performed in 2 patients, thermoablation - in 2 patients, and liver embolization in -1 patient.

\section{Acute complications after the $1^{\text {st }}$ course}

During the 1st course of PRRT, a slight but statistically significant decrease in the mean serum albumin concentration $(p<0.001)$ and ALT activity $(p=0.002)$, as well as an increase in the mean bilirubin concentration $(p=0.003)$, was observed (Tab. 2). However, these changes remained within the normal ranges. The type of therapy used, age, sex, BMl of the subjects, comorbidities, and the NEN point of origin did not affect the observed changes in hepatic parameters. It was only noted that in patients with a history of prior chemotherapy, the mean
Table 1. Characteristics of the study population

\begin{tabular}{|c|c|}
\hline Characteristics & Value \\
\hline \multicolumn{2}{|l|}{ Age (years) } \\
\hline Mean & $58.1 \pm 13.1$ \\
\hline Range & $23-76$ \\
\hline \multicolumn{2}{|l|}{ Sex } \\
\hline Women & 19 \\
\hline Men & 23 \\
\hline \multicolumn{2}{|l|}{ Place of residence } \\
\hline Village & 12 \\
\hline Town $<100,000$ citizens & 10 \\
\hline City $>100,000$ citizens & 20 \\
\hline \multicolumn{2}{|l|}{ BMI $\left(\mathrm{kg} / \mathrm{m}^{2}\right)$} \\
\hline Mean & $24.9 \pm 5.2$ \\
\hline Range & $16.4-41.3$ \\
\hline$<18.5$ & $3(7.1 \%)$ \\
\hline $18.5-24.9$ & $21(50 \%)$ \\
\hline $25.0-29.9$ & $12(28.6 \%)$ \\
\hline$\geq 30.0$ & $6(14.3 \%)$ \\
\hline \multicolumn{2}{|l|}{ Comorbidities } \\
\hline Chronic kidney disease G3 & $6(14.3 \%)$ \\
\hline Arterial hypertension & $18(42.9 \%)$ \\
\hline Diabetes mellitus & $12(28.6 \%)$ \\
\hline Hypercholesterolemia & $6(14.3 \%)$ \\
\hline \multicolumn{2}{|c|}{ Primary NENs point of origin } \\
\hline Pancreas & $15(35.6 \%)$ \\
\hline Jejunum & $13(30.9 \%)$ \\
\hline Colon & $5(12 \%)$ \\
\hline Others & $\begin{array}{c}5(12 \%)(2 \times \text { ovary, } 1 \times \text { stomach } \\
1 \times \text { paraganglioma } 1 \times \text { lung })\end{array}$ \\
\hline Unknown & $4(9.5 \%)$ \\
\hline \multicolumn{2}{|l|}{ Grading } \\
\hline G1 & $20(48 \%)$ \\
\hline G2 & $22(52 \%)$ \\
\hline G3 & 0 \\
\hline
\end{tabular}

BMI — body mass index

concentration of bilirubin slightly decreased after the first administration of radioisotopes $(p<0.001)$.

\section{Acute complications after the $4^{\text {th }}$ course}

The biochemical parameters assessing liver function obtained during the 4th course are presented in Table 3. There was a slight, statistically significant decrease in serum albumin concentration ( $p<0.001$ ); however, it remained within the normal limits. There was no correlation between changes in albumin concentration and age, sex, and BMl of the subjects, the presence of chronic diseases, the NEN point of origin, and the type of therapy used. There were also no other significant changes in the parameters of hepatocyte injury. 
Table 2. Changes in hepatic parameters during the first peptide receptor radionuclide therapy (PRRT) course

\begin{tabular}{|c|c|c|c|c|c|c|c|c|c|c|c|c|c|c|c|}
\hline \multirow[t]{2}{*}{ Parameter } & \multicolumn{2}{|c|}{$\begin{array}{c}\text { Before the } 1^{\text {st }} \\
\text { course } \\
(n=36)\end{array}$} & \multicolumn{2}{|c|}{$\begin{array}{l}\text { After the } 1^{\text {st }} \\
\text { course } \\
(n=36)\end{array}$} & \multirow[b]{2}{*}{$p$} & \multicolumn{2}{|c|}{$\begin{array}{c}{\left[{ }^{177} \mathrm{Lu}\right] \text { Lu-DO- }} \\
\text { TATATE } \\
(\mathrm{n}=27)\end{array}$} & \multicolumn{2}{|c|}{$\begin{array}{c}{\left[{ }^{90} \mathrm{Y}\right] \mathrm{Y} /\left[{ }^{177} \mathrm{Lu}\right]} \\
\text { Lu-DOTATATE } \\
(\mathrm{n}=9)\end{array}$} & \multirow[b]{2}{*}{$p$} & \multicolumn{2}{|c|}{$\begin{array}{c}\text { Pancreas } \\
(n=13)\end{array}$} & \multicolumn{2}{|c|}{$\begin{array}{l}\text { Other locations } \\
\qquad(n=23)\end{array}$} & \multirow[b]{2}{*}{$p$} \\
\hline & M & SD & M & SD & & $\Delta$ & SD & $\Delta$ & SD & & $\Delta$ & SD & $\Delta$ & SD & \\
\hline $\begin{array}{l}\text { Serum } \\
\text { albumin } \\
\text { [mg/dL] }\end{array}$ & 4.52 & 0.51 & 4.28 & 0.53 & $<0.001$ & -0.30 & 0.34 & -0.17 & 0.23 & 0.275 & -0.26 & 0.40 & -0.27 & 0.28 & 0.945 \\
\hline AST [IU/L] & 25.48 & 10.97 & 23.33 & 9.92 & 0.086 & -2.66 & 8.52 & -0.82 & 5.12 & 0.509 & -1.23 & 5.36 & -2.59 & 8.69 & 0.608 \\
\hline ALT [IU/L] & 25.80 & 18.20 & 22.20 & 14.88 & 0.002 & -2.76 & 8.12 & -6.00 & 4.47 & 0.220 & -4.64 & 9.11 & -3.12 & 6.42 & 0.540 \\
\hline $\begin{array}{l}\text { Bilirubin } \\
\text { [mg/dL] }\end{array}$ & 0.65 & 0.42 & 0.76 & 0.45 & 0.003 & 0.09 & 0.20 & 0.15 & 0.25 & 0.463 & 0.13 & 0.23 & 0.09 & 0.20 & 0.611 \\
\hline
\end{tabular}

AST — aspartate aminotransferase; ALT — alanine aminotransferase; M — mean, $\Delta$ — change; SD — standard deviation; $\mathrm{p}$ — the level of significance

Table 3. Changes in hepatic parameters during the $4^{\text {th }}$ peptide receptor radionuclide therapy (PRRT) course

\begin{tabular}{|c|c|c|c|c|c|c|c|c|c|c|c|c|c|c|c|}
\hline \multirow[t]{2}{*}{ Parameter } & \multicolumn{2}{|c|}{$\begin{array}{c}\text { Before the } 4^{\text {th }} \\
\text { course } \\
(n=30)\end{array}$} & \multicolumn{2}{|c|}{$\begin{array}{c}\text { After the } 4^{\text {th }} \\
\text { course } \\
(n=30)\end{array}$} & \multirow[b]{2}{*}{$p$} & \multicolumn{2}{|c|}{$\begin{array}{l}\text { [177Lu]Lu-DO- } \\
\text { TATATE } \\
(n=23)\end{array}$} & \multicolumn{2}{|c|}{$\begin{array}{c}{\left[{ }^{90} \mathrm{Y}\right] \mathrm{Y} /\left[{ }^{177} \mathrm{Lu}\right]} \\
\text { Lu-DOTATATE } \\
(\mathrm{n}=7)\end{array}$} & \multirow[b]{2}{*}{$p$} & \multicolumn{2}{|c|}{$\begin{array}{l}\text { Pancreas } \\
(n=11)\end{array}$} & \multicolumn{2}{|c|}{$\begin{array}{l}\text { Other locations } \\
\qquad(n=19)\end{array}$} & \multirow[b]{2}{*}{$p$} \\
\hline & M & SD & M & SD & & $\Delta$ & SD & $\Delta$ & SD & & $\Delta$ & SD & $\Delta$ & SD & \\
\hline $\begin{array}{l}\text { Serum albumin } \\
{[\mathrm{mg} / \mathrm{dL}]}\end{array}$ & 4.57 & 0.33 & 4.37 & 0.33 & $<0.001$ & -0.20 & 0.26 & -0.21 & 0.22 & 0.922 & -0.16 & 0.25 & -0.23 & 0.26 & 0.433 \\
\hline AST [IU/L] & 24.34 & 9.05 & 22.71 & 7.71 & 0.106 & -2.22 & 5.74 & 0.38 & 5.90 & 0.272 & -1.91 & 4.74 & -1.50 & 6.31 & 0.850 \\
\hline ALT [IU/L] & 23.42 & 12.82 & 21.56 & 11.47 & 0.382 & -2.50 & 5.22 & 0.43 & 8.96 & 0.434 & -2.46 & 7.16 & -1.59 & 5.53 & 0.690 \\
\hline $\begin{array}{l}\text { Bilirubin } \\
{[\mathrm{mg} / \mathrm{dL}]}\end{array}$ & 0.62 & 0.40 & 0.71 & 0.48 & 0.110 & 0.04 & 0.14 & 0.29 & 1.05 & 0.557 & -0.05 & 0.28 & 0.17 & 0.54 & 0.196 \\
\hline
\end{tabular}

AST — aspartate aminotransferase, ALT — alanine aminotransferase, M — mean, $\Delta$ — change, SD — standard deviation, $\mathrm{p}$ — the level of significance

Table 4. Changes in hepatic parameters before treatment initiation and before the $4^{\text {th }}$ peptide receptor radionuclide therapy (PRRT) course

\begin{tabular}{|c|c|c|c|c|c|c|c|c|c|c|c|c|c|c|c|}
\hline \multirow[t]{2}{*}{ Parameter } & \multicolumn{2}{|c|}{$\begin{array}{c}\text { Before the } 1^{\text {st }} \\
\text { course } \\
(n=30)\end{array}$} & \multicolumn{2}{|c|}{$\begin{array}{l}\text { Before the } 4^{\text {th }} \\
\text { course } \\
(n=30)\end{array}$} & \multirow[b]{2}{*}{$p$} & \multicolumn{2}{|c|}{$\begin{array}{c}{\left[{ }^{177} \mathrm{Lu}\right] \mathrm{Lu}-\mathrm{DO}-} \\
\text { TATATE } \\
(\mathrm{n}=23)\end{array}$} & \multicolumn{2}{|c|}{$\begin{array}{c}{\left[{ }^{90} \mathrm{Y}\right] \mathrm{Y} /\left[{ }^{177} \mathrm{Lu}\right]} \\
\text { Lu-DOTATATE } \\
(\mathrm{n}=7)\end{array}$} & \multirow[b]{2}{*}{$p$} & \multicolumn{2}{|c|}{$\begin{array}{l}\text { Pancreas } \\
(n=11)\end{array}$} & \multicolumn{2}{|c|}{$\begin{array}{c}\text { Other } \\
\text { locations } \\
(n=19)\end{array}$} & \multirow[b]{2}{*}{$p$} \\
\hline & M & SD & M & SD & & $\Delta$ & SD & $\Delta$ & SD & & $\Delta$ & SD & $\Delta$ & SD & \\
\hline $\begin{array}{l}\text { Serum albumin } \\
{[\mathrm{mg} / \mathrm{dL}]}\end{array}$ & 4.61 & 0.39 & 4.58 & 0.33 & 0.564 & -0.09 & 0.32 & 0.17 & 0.38 & 0.075 & -0.05 & 0.35 & -0.02 & 0.35 & 0.810 \\
\hline AST [IU/L] & 24.82 & 10.54 & 24.56 & 9.09 & 0.858 & -0.69 & 9.41 & 1.13 & 5.38 & 0.608 & 0.10 & 8.06 & -0.42 & 8.96 & 0.876 \\
\hline ALT [IU/L] & 25.91 & 19.14 & 23.60 & 12.96 & 0.756 & -3.41 & 16.43 & 1.71 & 15.87 & 0.465 & -2.00 & 21.75 & -2.57 & 12.25 & 0.922 \\
\hline Bilirubin [mg/dL] & 0.64 & 0.43 & 0.63 & 0.40 & 0.685 & -0.05 & 0.29 & 0.13 & 0.31 & 0.159 & -0.02 & 0.36 & -0.01 & 0.27 & 0.992 \\
\hline
\end{tabular}

AST — aspartate aminotransferase, ALT — alanine aminotransferase, M - mean, $\Delta$ - change, SD — standard deviation, $\mathrm{p}$ - the level of significance

\section{Chronic complications}

\section{$1^{\text {st }}$ course vs $4^{\text {th }}$ course - the first assessment of chronic hepatic complications}

Before the $4^{\text {th }}$ course, as compared to the tests performed before the 1st course (i.e., after approx. eight months from the start of PRRT), no biochemical features of hepatocyte damage or disturbances in the synthetic function of the liver were found (Tab. 4).

\section{$4^{\text {th }}$ course vs follow-up visit - the $2^{\text {nd }}$ assessment of chronic hepatic complications}

In the second long-term evaluation, in the control tests compared to the tests before the $4^{\text {th }}$ course (approximately ten months after the end of PRRT), a slight statistically significant ( $p=0.007)$ increase in
ALT, remaining within the reference range, was found. This increase was statistically significantly higher in the group of patients receiving tandem therapy $(p=0.010)$ and in the group of patients with the NEN point of origin in the pancreas $(p=0.049)$. The increase in ALT was also higher in men $(p=0.015)$ and patients with diabetes $(p=0.024)$. However, no disturbances in the synthetic function of the liver were found. Detailed results are presented in Table 5.

\section{$1^{\text {st }}$ course vs follow-up visit - the long-term assessment of hepatic complications}

In the follow-up at 18 months after the start of treatment, compared to the baseline lab tests before the first course of therapy, in the entire group of patients, no biochemical features of hepatocyte injury or disturbances in the synthetic function of the liver were 
Table 5. Changes in hepatic parameters before the $4^{\text {th }}$ peptide receptor radionuclide therapy (PRRT) course and the follow-up

\begin{tabular}{|c|c|c|c|c|c|c|c|c|c|c|c|c|c|c|c|}
\hline \multirow[t]{2}{*}{ Parameter } & \multicolumn{2}{|c|}{$\begin{array}{c}\text { Before the } 4^{\text {th }} \\
\text { course } \\
(n=19)\end{array}$} & \multicolumn{2}{|c|}{$\begin{array}{l}\text { Follow-up } \\
(n=19)\end{array}$} & & \multicolumn{2}{|c|}{$\begin{array}{l}\text { [177 Lu]Lu-DO- } \\
\text { TATATE } \\
(n=16)\end{array}$} & \multicolumn{2}{|c|}{$\begin{array}{c}{\left[{ }^{90} \mathrm{Y}\right] \mathrm{Y} /\left[{ }^{177} \mathrm{Lu}\right]} \\
\text { Lu-DOTATATE } \\
\quad(\mathrm{n}=3)\end{array}$} & \multirow[b]{2}{*}{$p$} & \multicolumn{2}{|c|}{$\begin{array}{l}\text { Pancreas } \\
(\mathrm{n}=7)\end{array}$} & \multicolumn{2}{|c|}{$\begin{array}{l}\text { Other locations } \\
\qquad(n=12)\end{array}$} & \multirow[b]{2}{*}{$p$} \\
\hline & M & SD & M & SD & $p$ & $\Delta$ & SD & $\Delta$ & SD & & $\Delta$ & SD & $\Delta$ & SD & \\
\hline $\begin{array}{l}\text { Serum } \\
\text { albumin } \\
{[\mathrm{mg} / \mathrm{dL}]}\end{array}$ & 4.60 & 0.42 & 4.51 & 0.40 & 0.172 & -0.06 & 0.40 & -0.30 & 0.36 & 0.343 & 0.09 & 0.37 & -0.20 & 0.39 & 0.133 \\
\hline AST [IU/L] & 29.42 & 16.68 & 25.42 & 10.00 & 0.402 & 5.25 & 20.51 & 17.67 & 11.02 & 0.329 & 6.71 & 8.88 & 7.50 & 24.24 & 0.936 \\
\hline ALT [IU/L] & 23.95 & 14.18 & 26.95 & 20.82 & 0.007 & 0.44 & 8.81 & 16.67 & 9.29 & 0.010 & 9.14 & 10.75 & -0.58 & 9.00 & 0.049 \\
\hline $\begin{array}{l}\text { Bilirubin } \\
{[\mathrm{mg} / \mathrm{dL}]}\end{array}$ & 0.70 & 0.46 & 0.64 & 0.35 & 0.309 & -0.03 & 0.20 & 0.17 & 0.06 & 0.118 & 0.06 & 0.21 & -0.03 & 0.19 & 0.356 \\
\hline
\end{tabular}

AST — aspartate aminotransferase, ALT — alanine aminotransferase, M — mean, $\Delta$ — change, SD — standard deviation, $p$ — the level of significance

Table 6. Changes in hepatic parameters before the initiation of therapy and in the follow-up visit

\begin{tabular}{|c|c|c|c|c|c|c|c|c|c|c|c|c|c|c|c|}
\hline \multirow[t]{2}{*}{ Parameter } & \multicolumn{2}{|c|}{$\begin{array}{l}\text { Before the } 1^{\text {st }} \\
\text { course } \\
(n=19)\end{array}$} & \multicolumn{2}{|c|}{$\begin{array}{l}\text { Follow-up } \\
(n=19)\end{array}$} & \multicolumn{3}{|c|}{$\begin{array}{c}{[177 \text { Lu]Lu-DO- }} \\
\text { TATATE } \\
(n=16)\end{array}$} & \multicolumn{2}{|c|}{$\begin{array}{c}{\left[{ }^{90} \mathrm{Y}\right] \mathrm{Y} /\left[{ }^{177} \mathrm{Lu}\right]} \\
\text { Lu-DOTATATE } \\
(\mathrm{n}=3)\end{array}$} & \multirow[b]{2}{*}{$p$} & \multicolumn{2}{|c|}{$\begin{array}{l}\text { Pancreas } \\
(n=7)\end{array}$} & \multicolumn{2}{|c|}{$\begin{array}{l}\text { Other locations } \\
\qquad(n=12)\end{array}$} & \multirow[b]{2}{*}{$p$} \\
\hline & M & SD & M & SD & $p$ & $\Delta$ & SD & $\Delta$ & SD & & $\Delta$ & SD & $\Delta$ & SD & \\
\hline $\begin{array}{l}\text { Serum } \\
\text { albumin } \\
\text { [mg/dL] }\end{array}$ & 4.61 & 0.43 & 4.51 & 0.40 & 0.712 & 0.19 & 0.48 & 0.17 & 0.25 & 0.927 & 0.26 & 0.44 & 0.15 & 0.47 & 0.629 \\
\hline AST [IU/L] & 29.33 & 17.16 & 26.11 & 10.17 & 0.545 & 4.69 & 19.41 & 17.00 & 9.54 & 0.306 & 4.00 & 10.52 & 8.17 & 22.31 & 0.651 \\
\hline ALT [IU/L] & 26.11 & 23.70 & 26.95 & 20.82 & 0.232 & -0.13 & 13.58 & 23.33 & 22.50 & 0.023 & 5.57 & 22.55 & 2.42 & 13.73 & 0.707 \\
\hline $\begin{array}{l}\text { Bilirubin } \\
{[\mathrm{mg} / \mathrm{dL}]}\end{array}$ & 0.68 & 0.36 & 0.64 & 0.35 & 0.505 & -0.19 & 0.36 & -0.13 & 0.55 & 0.807 & -0.33 & 0.36 & -0.10 & 0.38 & 0.212 \\
\hline
\end{tabular}

AST — aspartate aminotransferase, ALT — alanine aminotransferase, M — mean, $\Delta$ - change, SD — standard deviation, $\mathrm{p}$ — the level of significance

found. However, it was noticed that in the group of patients treated with $\left[{ }^{90} \mathrm{Y}\right] \mathrm{Y} /\left[{ }^{177} \mathrm{Lu}\right] \mathrm{Lu}-\mathrm{DOTATATE}$, there was a statistically significant increase in ALT ( $p=0.023)$, and in the group of patients receiving chemotherapy in the past, a slight increase in bilirubin concentration, but within the reference range $(p=0.017)$ was observed. Detailed results are presented in Table 6.

\section{Hepatic complications of PRRT according to CTCAE version 5.0}

According to the Common Terminology Criteria for Adverse Events (CTCAE v 5.0) of the US National Cancer Institute, early and late hepatic complications are presented in Tables 7 and 8. Grade 3 and 4 (G3, G4) hepatic complications were not observed after the first administration of radioisotopes. On the other hand, a slight decrease in albumin concentration was found, which caused an increase in adverse event grade 1 and 2 groups. After the first PRRT course, an increase in bilirubin concentration was also noticed, as a result of which an increase in G1 and G2 groups was also found (Tab. 7). In the evaluation of long-term complications, no grade 2, 3, or 4 (G2, G3, G4) hepatic complications were found (Tab. 8).

\section{Discussion}

In the presented study, no hepatotoxicity of the applied radioisotope treatment was found in both short and long-term follow-up. The presence of metastatic lesions in the liver, which occurred in
$91.7 \%$ of the patients, prior chemotherapy and previous locoregional treatment aimed at metastatic lesions in the liver also did not affect the deterioration of liver parameters. The slight increase in ALT activity was associated with tandem therapy, the location of the NENs primary origin in the pancreas, and the diagnosis of diabetes at the follow-up visit.

In the available literature, hepatotoxicity is also a rare complication of PRRT. It has been most frequently reported in patients with large and extensive hepatic metastases (size $>5 \mathrm{~cm}$ ) [21, 22]. In the NETTER-1 study, the elevation of AST activity of grade 3 or 4 according to CTCAE v 5.0 was found in $4.5 \%, A L T$ - in $3.6 \%$, and bilirubin concentration - in 1.8\% of patients [23]. Brabander et al. [24], in a study assessing long-term efficacy, survival, and safety of [ $\left.{ }^{177} \mathrm{Lu}\right] \mathrm{Lu}$-DOTATATE, noticed the elevated activity of AST and/or ALT (grades 3 or 4 CTCAE v 4.0) only in $3 \%$ of patients.

In the literature, patients with NENs with little or no hepatic metastases showed no evidence of significant liver injury [25-27]. However, severe liver damage may occur in a group of patients with extensive liver metastases and/or abnormal liver function. In other words, the safety of using PRRT in a patient with $25 \%$ liver involvement is not the same as the safety of treating a patient with $50 \%$, or even $75 \%$, organ involvement. They should also be considered in the case of preexisting liver disease or conditions affecting liver function. Then it is important to choose the right radioisotope and its activity. In such cases, Lutetium-177 labeled peptides are recommended, and the reported activity should be appropriately 
Table 7. Early complications according to the Common Terminology Criteria for Adverse Events (CTCAE v 5.0) classification

\begin{tabular}{|c|c|c|c|c|c|c|c|}
\hline & Befo & ourse & & $1^{\text {st }}$ cours & & In total before the & In total after the $1^{\text {st }}$ \\
\hline & G1 (\%) & G2 (\%) & G1 (\%) & G2 (\%) & G3 (\%) & $1^{\text {st }}$ course $(\%)$ & course (\%) \\
\hline $\begin{array}{l}\text { Serum albumin } \\
{[\mathrm{mg} / \mathrm{dL}]}\end{array}$ & $2(5.6)$ & $1(2.8)$ & $3(7.7)$ & $2(5.1)$ & 0 & $3 / 36(8.4)$ & 5/36 (12.8) \\
\hline AST [IU/L] & $5(13.9)$ & 0 & 2 (5) & 0 & 0 & $5 / 36(13.9)$ & 2/36 (5) \\
\hline ALT [IU/L] & $6(16.7)$ & 0 & $4(10)$ & 0 & 0 & 6/36 (16.7) & 4/36 (10) \\
\hline Bilirubin [mg/dL] & $1(2.8)$ & $1(2.8)$ & $3(7.5)$ & 2 (5) & 0 & 2/36 (5.6) & $5 / 36(12.5)$ \\
\hline
\end{tabular}

AST — aspartate aminotransferase, ALT — alanine aminotransferase

Table 8. Long-term complications according to the Common Terminology Criteria for Adverse Events (CTCAE v 5.0) classification

\begin{tabular}{|c|c|c|c|c|c|c|c|}
\hline & \multicolumn{2}{|c|}{ Before the $1^{\text {st }}$ course } & \multicolumn{3}{|c|}{ Follow-up } & \multirow{2}{*}{$\begin{array}{l}\text { In total before the } \\
1^{\text {st }} \text { course }(\%)\end{array}$} & \multirow{2}{*}{$\begin{array}{c}\text { In total at follow-up } \\
(\%)\end{array}$} \\
\hline & G1 (\%) & G2 (\%) & G1 (\%) & G2 (\%) & G3 (\%) & & \\
\hline $\begin{array}{l}\text { Serum albumin } \\
{[\mathrm{mg} / \mathrm{dL}]}\end{array}$ & $2(5.6)$ & $1(2.8)$ & 1 (5.3) & 0 & 0 & $3 / 36(8.4)$ & 1/19 (5.3) \\
\hline AST [IU/L] & $5(13.9)$ & 0 & 5 (26.3) & 0 & 0 & 5/36 (13.9) & 5/19 (26.3) \\
\hline ALT [IU/L] & $6(16.7)$ & 0 & $3(15.8)$ & 0 & 0 & 6/36 (16.7) & 3/19 (15.8) \\
\hline
\end{tabular}

AST — aspartate aminotransferase, ALT — alanine aminotransferase

reduced. In 2015 there were published the results of a retrospective study in which 17 patients from the United States of America (USA) were treated with a radioisotope in a Swiss center in Basel. The study evaluated 93 patients with confirmed NENs with liver metastases. Seventeen subjects (18\%), after confirming disease progression despite using other traditional therapies available in the USA at that time, were qualified for PRRT treatment in various regimens using various radioisotopes: Yttrium-90, Lutetium-177, Indium-11, or tandem therapy (Lutetium-177 with Yttrium-90). The two study groups (treated or not with PRRT) did not differ in sex, age, baseline laboratory parameters, prior exposure to treatment, or disease duration. In the group not subjected to PRRT, 23 of 76 (30\%) patients had increased liver injury markers associated with the use of traditional GEP NET therapy (surgery, chemoembolization, treatment [131]]-meta-iodobenzylguanidine). In 10 of 17 (59\%) patients treated with PRRT, biochemical features of liver injury were found, while ascites occurred in $41 \%$ of patients in this group, compared with $6.5 \%$ in the second cohort. The higher incidence of hepatotoxicity in that group treated with radioisotope therapy, significantly higher than the one reported so far, could result from the delayed duration of PRRT use (this therapy was not available in the USA at that time) and the previous use of locoregional therapy (surgical treatment, chemoembolization or thermoablation of focal lesions in the liver, $\left[{ }^{[31} 1\right]$ I-MIBG treatment), causing more radiation damage to the liver [28].

In the study published in 2020 by Spanish researchers, one patient (out of a total of 36 treated with [ ${ }^{177} \mathrm{Lu}$ ]Lu-DOTATATE) with extensive liver metastases present had a significant degree of liver injury. Liver parameters deteriorated within weeks after the first administration of the radioisotope, and the patient died of liver failure five weeks later. In the remaining 35 subjects, however, no signs of liver injury were observed [29]. Therefore, there are concerns regarding the safety of radioisotope therapy in patients with high liver involvement by metastatic lesions due to the possibility of radiation hepatitis. However, data published in 2020 from the NETTER-1 study did not support this hypothesis. The increase in liver injury markers was rare and did not appear to correlate with the extent of the neoplastic disease [30]. In the NETTER-1 study, the subgroup of patients with extreme liver parenchymal involvement (>90\%) was not defined; therefore, no detailed safety analysis could be made in this subgroup.

In many patients, NENs are detected when the disease is already advanced. Often, however, it is limited to the liver only, where it is metastasizing from the intestines. In some cases, it is suggested to combine selective internal radiotherapy and PRRT by administering a somatostatin analog conjugated with Lutetium-177 or Yttrium-90 directly through the hepatic artery [31]. Theoretically, this ensures the delivery of higher radioisotope activity to the tumor itself (improving the effectiveness of treatment) while reducing its activity in the systemic circulation (reducing side effects). Initial results of such therapy show that it can be successfully used [31]. Moreover, radioembolization of metastatic lesions in the liver after systemic radionuclide treatment was also shown to be safe, and liver damage induced by this procedure was shown to be rare [32] . However, studies directly comparing these forms of therapy with systemic PRRT administration have not been conducted so far [33].

In our study, we did not observe any significant deterioration of liver parameters. This is most likely since PRRT has been used in Poland for almost 20 years and is a therapeutic option started in the early stages of NEN progression when there is no significant involvement of the liver parenchyma by metastatic lesions. In the presented study, five patients underwent prior locoregional treatment (hemihepatectomy -2 patients, thermal ablation -2 patients, or embolization of liver lesions -1 patient) before starting PRRT, which may have somewhat reduced the adverse events of PRRT on liver function in our study. Furthermore, both in our study and the available literature, the type of radioisotope therapy used did not deteriorate liver parameters and function. 


\section{Study limitations}

The presented paper, although preliminary, is one of the few prospective studies; however, it has some limitations. First, the study was conducted on a relatively small number of patients. Despite almost two years of recruitment, and in the center with a large number of isotope therapies per year, and the low incidence of neuroendocrine neoplasms, it was impossible to collect the larger group. The COVID-19 pandemic also played a significant role in this regard, due to which some patients did not survive to the end of the study or follow-up visit. Nevertheless, the presented group allowed obtaining many important and interesting results that undoubtedly require further research.

\section{Conclusions}

Our study showed that radioisotope treatment and its type did not affect the liver parameters in both early and long-term follow-up. Regarding liver function, treatment of NENs using Lutetium-177 or Yttrium-90/Lutetium-177 isotopes appeared to be safe.

\section{Conflict of interest}

None declared.

\section{References}

1. Modlin IM, Lye KD, Kidd M. A 5-decade analysis of 13,715 carcinoid tumors. Cancer. 2003; 97(4): 934-959, doi: 10.1002/cncr.11105, indexed in Pubmed: 12569593.

2. Chamberlain R, Canes D, Brown K, et al. Hepatic neuroendocrine metastases: does intervention alter outcomes? J Am Coll Surg. 2000; 190(4): 432-445, doi: 10.1016/s1072-7515(00)00222-2.

3. Yao JC, Hassan M, Phan A, et al. One hundred years after "carcinoid": epidemiology of and prognostic factors for neuroendocrine tumors in 35,825 cases in the United States. J Clin Oncol. 2008; 26(18): 3063-3072, doi: 10.1200/JCO.2007.15.4377, indexed in Pubmed: 18565894

4. Niederle B, Pape UF, Costa F, et al. ENETS Consensus Guidelines Update for Neuroendocrine Neoplasms of the Jejunum and lleum. Neuroendocrinology. 2016; 103(2): 125-138, doi: 10.1159/000443170, indexed in Pubmed: 26758972.

5. Bednarczuk T, Bolanowski M, Zemczak A, et al. Neuroendocrine neoplasms of the small intestine and appendix - management guidelines (recommended by the Polish Network of Neuroendocrine Tumours). Endokrynol Pol. 2017; 68(2): 223-236, doi: 10.5603/EP.2017.0018, indexed in Pubmed: 28540974.

6. Plöckinger U, Rindi G, Arnold R, et al. European Neuroendocrine Tumour Society. Guidelines for the diagnosis and treatment of neuroendocrine gastrointestinal tumours. A consensus statement on behalf of the European Neuroendocrine Tumour Society (ENETS). Neuroendocrinology. 2004; 80(6): 394-424, doi: 10.1159/000085237, indexed in Pubmed: 15838182.

7. Öberg K, Knigge U, Kwekkeboom D, et al. ESMO Guidelines Working Group. Neuroendocrine gastro-entero-pancreatic tumors: ESMO Clinical Practice Guidelines for diagnosis, treatment and follow-up. Ann Oncol. 2012; 23 Suppl 7: vii124-vii130, doi: 10.1093/annonc/mds295, indexed in Pubmed: 22997445.

8. Kos-Kudła B, Rosiek V, Borowska M, et al. Pancreatic neuroendocrine neoplasms - management guidelines (recommended by the Polish Network of Neuroendocrine Tumours). Endokrynol Pol. 2017; 68(2): 169-197, doi: 10.5603/EP.2017.2016, indexed in Pubmed: 28540973.
9. Kos-Kudła B, Blicharz-Dorniak J, Strzelczyk J, et al. Diagnostic and therapeutic guidelines for gastro-entero-pancreatic neuroendocrine neoplasms (recommended by the Polish Network of Neuroendocrine Tumours). Endokrynol Pol. 2017; 68(2): 79-110, doi: 10.5603/EP.2017.0015, indexed in Pubmed: 28597909.

10. Kulke MH, Siu LL, Tepper JE, et al. Future directions in the treatment of neuroendocrine tumors: consensus report of the National Cancer Institute Neuroendocrine Tumor clinical trials planning meeting. J Clin Oncol. 2011; 29(7): 934-943, doi: 10.1200/JCO.2010.33.2056, indexed in Pubmed: 21263089

11. Ito $\mathrm{T}$, Hijioka $\mathrm{S}$, Masui $\mathrm{T}$, et al. Advances in the diagnosis and treatment of pancreatic neuroendocrine neoplasms in Japan. J Gastroenterol. 2017; 52(1): 9-18, doi: 10.1007/s00535-016-1250-9, indexed in Pubmed: 27539256

12. Alonso-Gordoa T, Capdevila J, Grande E. GEP-NETs update: Biotherapy for neuroendocrine tumours. Eur J Endocrinol. 2015; 172(1): R31-R46, doi: 10.1530/EJE-14-0354, indexed in Pubmed: 25430657.

13. Kolasińska-Ćwikła A, Łowczak A, Maciejkiewicz KM, et al. Peptide Receptor Radionuclide Therapy for Advanced Gastroenteropancreatic Neuroendocrine Tumors - from oncology perspective. Nucl Med Rev Cent East Eur. 2018; 21 (2), doi: 10.5603/NMR.2018.0019, indexed in Pubmed: 29741203.

14. Navalkissoor S, Grossman A. Targeted Alpha Particle Therapy for Neuroendocrine Tumours: The Next Generation of Peptide Receptor Radionuclide Therapy. Neuroendocrinology. 2019; 108(3): 256-264, doi: 10.1159/000494760, indexed in Pubmed: 30352433.

15. Kunikowska J, Pawlak D, Bąk MI, et al. Long-term results and tolerability of tandem peptide receptor radionuclide therapy with Y/Lu-DOTATATE in neuroendocrine tumors with respect to the primary location: a 10-year study. Ann Nucl Med. 2017; 31(5): 347-356, doi: 10.1007/s12149-017-1163-6, indexed in Pubmed: 28316066.

16. Bodei L, Ferone D, Grana CM, et al. Peptide receptor therapies in neuroendocrine tumors. J Endocrinol Invest. 2009; 32(4): 360-369, doi: 10.1007/BF03345728, indexed in Pubmed: 19636207.

17. Imhof A, Brunner P, Marincek N, et al. Response, survival, and longterm toxicity after therapy with the radiolabeled somatostatin analogue [90Y-DOTA]-TOC in metastasized neuroendocrine cancers. J Clin Oncol. 2011; 29(17): 2416-2423, doi: 10.1200/JCO.2010.33.7873, indexed in Pubmed: 21555692.

18. Pfeifer AK, Gregersen T, Grønbæk H, et al. Peptide receptor radionuclide therapy with Y-DOTATOC and (177)Lu-DOTATOC in advanced neuroendocrine tumors: results from a Danish cohort treated in Switzerland. Neuroendocrinology. 2011; 93(3): 189-196, doi: 10.1159/000324096, indexed in Pubmed: 21335949.

19. Waldherr $\mathrm{C}$, Pless $\mathrm{M}, \mathrm{Maecke} \mathrm{HR}$, et al. Tumor response and clinical benefit in neuroendocrine tumors after 7.4 GBq (90)Y-DOTATOC. J Nucl Med. 2002; 43(5): 610-616, indexed in Pubmed: 11994522.

20. Sabet A, Ezziddin K, Pape UF, et al. Accurate assessment of long-term nephrotoxicity after peptide receptor radionuclide therapy with (177) Lu-octreotate. Eur J Nucl Med Mol Imaging. 2014; 41(3): 505-510, doi: 10.1007/s00259-013-2601-x, indexed in Pubmed: 24196919.

21. Kendi AT, Halfdanarson TR, Packard A, et al. Therapy With Lu-DOTATATE: Clinical Implementation and Impact on Care of Patients With Neuroendocrine Tumors. AJR Am J Roentgenol. 2019; 213(2): 309-317, doi: 10.2214/AJR.19.21123, indexed in Pubmed: 31039017.

22. Frilling A, Li J, Malamutmann E, et al. Treatment of liver metastases from neuroendocrine tumours in relation to the extent of hepatic disease. $\mathrm{Br} \mathrm{J}$ Surg. 2009; 96(2): 175-184, doi: 10.1002/bjs.6468, indexed in Pubmed: 19160361.

23. Strosberg J, El-Haddad G, Wolin E, et al. NETTER-1 Trial Investigators. Phase 3 Trial of Lu-Dotatate for Midgut Neuroendocrine Tumors. N Engl J Med. 2017; 376(2): 125-135, doi: 10.1056/NEJMoa1607427, indexed in Pubmed: 28076709.

24. Brabander T, van der Zwan WA, Teunissen JJM, et al. Long-Term Efficacy, Survival, and Safety of [Lu-DOTA, Tyr]octreotate in Patients with Gastroen- 
teropancreatic and Bronchial Neuroendocrine Tumors. Clin Cancer Res. 2017; 23(16): 4617-4624, doi: 10.1158/1078-0432.CCR-16-2743, indexed in Pubmed: 28428192.

25. Kunikowska J, Zemczak A, Kołodziej M, et al. Tandem peptide receptor radionuclide therapy using $\mathrm{Y} / \mathrm{Lu}$-DOTATATE for neuroendocrine tumors efficacy and side-effects - polish multicenter experience. Eur J Nucl Med Mol Imaging. 2020; 47(4): 922-933, doi: 10.1007/s00259-020-04690-5, indexed in Pubmed: 31980909.

26. Zhang J, Kulkarni HR, Singh A, et al. Peptide Receptor Radionuclide Therapy in Grade 3 Neuroendocrine Neoplasms: Safety and Survival Analysis in 69 Patients. J Nucl Med. 2019; 60(3): 377-385, doi: 10.2967/jnumed.118.215848, indexed in Pubmed: 30115686

27. Zemczak A, Gut P, Pawlak D, et al. The Safety and Efficacy of the Repeated PRRT with [Y]Y/[Lu]Lu-DOTATATE in Patients with NET. Int J Endocrinol. 2021; 2021: 6615511, doi: 10.1155/2021/6615511, indexed in Pubmed: 33552155.

28. Riff BP, Yang YX, Soulen MC, et al. Peptide Receptor Radionuclide Therapy-Induced Hepatotoxicity in Patients With Metastatic Neuroendocrine Tumors. Clin Nucl Med. 2015; 40(11): 845-850, doi: 10.1097/RLU.0000000000000935, indexed in Pubmed: 26284763.
29. Abou Jokh Casas E, Pubul Núñez V, Anido-Herranz U, et al. Evaluation of Lu-Dotatate treatment in patients with metastatic neuroendocrine tumors and prognostic factors. World J Gastroenterol. 2020; 26(13): 1513-1524, doi: 10.3748/wjg.v26.i13.1513, indexed in Pubmed: 32308351.

30. Strosberg J, Kunz PL, Hendifar A, et al. Impact of liver tumour burden, alkaline phosphatase elevation, and target lesion size on treatment outcomes with Lu-Dotatate: an analysis of the NETTER-1 study. Eur J Nucl Med Mol Imaging. 2020; 47(10): 2372-2382, doi: 10.1007/s00259-020-04709-x, indexed in Pubmed: 32123969.

31. Kratochwil C, López-Benítez R, Mier W, et al. Hepatic arterial infusion enhances DOTATOC radiopeptide therapy in patients with neuroendocrine liver metastases. Endocr Relat Cancer. 2011; 18(5): 595-602, doi: 10.1530/ERC11-0144, indexed in Pubmed: 21791571.

32. Braat AJ, Ahmadzadehfar H, Kappadath SC, et al. Radioembolization with Y Resin Microspheres of Neuroendocrine Liver Metastases After Initial Peptide Receptor Radionuclide Therapy. Cardiovasc Intervent Radiol. 2020; 43(2): 246-253, doi: 10.1007/s00270-019-02350-2, indexed in Pubmed: 31646375.

33. Mittra ES. Neuroendocrine Tumor Therapy: Lu-DOTATATE. AJR Am J Roentgenol. 2018; 211(2): 278-285, doi: 10.2214/AJR.18.19953, indexed in Pubmed: 29949416. 